\title{
Problems of Population Reproduction and Migration in the USSR
}

\author{
LEONID RYBAKOVSKY \\ Professor \\ Institute of Sociological Research \\ USSR Academy of Sciences \\ GALINA KISELEVA \\ Senior Research Associate \\ Institute of Sociological Research \\ USSR Academy of Sciences
}

Among the studies devoted to Soviet population development the most salient place is taken by the analyses of natural increase and migration. In the USSR these processes are characterized by a number of peculiarities. For an understanding of these special features, it is necessary to be familiar with the demographic situation prevalent in prerevolutionary Russia. It is known that capitalist development in Russia commenced later than in other European countries. In addition, up to 1917 development was hampered by notable survivals of feudalism and serfdom; this was the case particularly in the areas inhabited by national minorities, for instance, in such large regions as Central Asia, Kazakhstan, and Caucasus.

Between 1861 and 1913 the average annual number of births and deaths in the 50 provinces of European Russia were 48.9 and 34.0 respectively per 1,000 inhabitants. The natural increase of the population accounted for 14.9 per thousand on the average per year (Rashin, 1966, 153). It was characteristic of the population in which the share of rural inhabitants was $82 \%$ in 1913 - that its migratory mobility was very low (Narkhoz 60,7).

The successful socioeconomic development of the USSR after the socialist revolution provided the basis for the emergence of a principally new type of population reproduction characterized for the majority of the population by a not high fertility and a relatively low mortality. The expectancy of life grew from 32 years at the beginning of the present century to 70 years in $1971-72$, i.e. it more than doubled (Narkhoz 60, 137). The territorial mobility of the population grew sharply.

In Table 1 the indicators of fertility, mortality, and natural increase of population are followed over a long period of time. It is possible to see from the table that the values of the crude birth rate show a tendency towards stabilization on a relatively low level; during the last few years, however, a slight rise in the birth rate can be seen. The crude death rate has grown gradually and the natural increase rate has declined lately (migration will be discussed below).

During the last 10 years the crude birth rate ranged from 18.1 to 18.9 per thousand, the crude death rate from 9.3 to 10.3 per thousand, and, consequently, the natural increase rate was at that time about $1 \%$. It can be noted that in comparison with most of the developed industrial countries the birth and natural increase coefficients in the Soviet Union have been significantly higher. For instance, in 1981 the number of births per 1,000 inhabitants was 18.5 while the corresponding figures (per thousand) were 15.9 in the United States, 13.1 in Great Britain, 14.9 in France, and 10.1 in the Federal Republic of Germany (Narkhoz 1982, 85, 87). 
$\mathrm{T}$ a b l e 1. Birth rates, death rates and rates of natural increase: USSR, selected years from 1913 to 1982.

\begin{tabular}{cccc} 
Year & \multicolumn{3}{c}{ Per 1000 inhabitants } \\
& Birth rate & Death rate & Natural increase \\
1913 & 45.5 & 29.1 & 16.4 \\
1940 & 31.2 & 18.0 & 13.2 \\
1950 & 26.7 & 9.7 & 17.0 \\
1955 & 25.7 & 8.2 & 17.2 \\
1960 & 24.9 & 7.1 & 17.8 \\
1965 & 18.4 & 7.3 & 11.1 \\
1970 & 17.4 & 8.2 & 9.2 \\
1975 & 18.1 & 9.3 & 8.8 \\
1980 & 18.3 & 10.3 & 8.0 \\
1981 & 18.5 & 10.2 & 8.3 \\
1982 & 18.9 & 10.1 & 8.8
\end{tabular}

Sources: Narkhoz 1979, 36; Narkhoz 1982, 30.

$\mathrm{T}$ a b l e 2. Total fertility rates: USSR and union republics, from 1969-70 to 1980-81 per woman.

\begin{tabular}{lllllllllllll|} 
& $1969-$ & $1971-$ & $1972-$ & $1973-$ & $1974-$ & $1975-$ & $1976-$ & $1977-$ & $1978-$ & $1979-$ & $1980-$ \\
& 1970 & 1972 & 1973 & 1974 & 1975 & 1976 & 1977 & 1978 & 1979 & 1980 & 1981 \\
USSR & 2.389 & 2.469 & 2.433 & 2.412 & 2.407 & 2.389 & 2.367 & 2.320 & 2.285 & 2.259 & 2.253 \\
Russian SFSR & 1.971 & 2.053 & 2.023 & 2.000 & 1.992 & 1.969 & 1.967 & 1.938 & 1.902 & 1.887 & 1.895 \\
Ukraine & 2.044 & 2.123 & 2.083 & 2.044 & 2.044 & 2.023 & 1.989 & 1.943 & 1.962 & 1.960 & 1.935 \\
White Russia & 2.298 & 2.337 & 2.284 & 2.233 & 2.198 & 2.139 & 2.105 & 2.069 & 2.058 & 2.037 & 2.023 \\
Uzbek & 5.636 & 5.841 & 5.669 & 5.706 & 5.679 & 5.660 & 5.483 & 5.247 & 5.096 & 4.905 & 4.805 \\
Kazakh & 3.307 & 3.366 & 3.319 & 3.313 & 3.299 & 3.258 & 3.213 & 3.131 & 3.025 & 2.939 & 2.911 \\
Georgia & 2.616 & 2.611 & 2.572 & 3.577 & 2.536 & 2.516 & 2.450 & 2.355 & 2.294 & 2.251 & 2.249 \\
Azerbaidzhan & 4.633 & 4.301 & 4.132 & 4.035 & 3.949 & 3.916 & 3.822 & 3.642 & 3.484 & 3.329 & 3.227 \\
Lithuania & 2.354 & 2.376 & 2.289 & 2.227 & 2.201 & 2.185 & 2.161 & 2.112 & 2.067 & 2.011 & 1.976 \\
Moldavia & 2.563 & 2.630 & 2.626 & 2.537 & 2.564 & 2.518 & 2.458 & 2.392 & 2.384 & 2.382 & 2.403 \\
Latvia & 1.926 & 2.010 & 1.986 & 1.972 & 1.981 & 1.946 & 1.910 & 1.874 & 1.865 & 1.880 & 1.887 \\
Kirgiz & 4.846 & 4.968 & 4.889 & 4.807 & 4.753 & 4.850 & 4.783 & 4.558 & 4.410 & 4.135 & 4.089 \\
Tadzhik & 5.903 & 6.153 & 6.071 & 6.196 & 6.265 & 6.313 & 6.160 & 5.988 & 5.970 & 5.760 & 5.627 \\
Armenia & 3.195 & 3.170 & 3.070 & 2.913 & 2.819 & 2.786 & 2.603 & 2.603 & 2.450 & 2.383 & 2.339 \\
Turkmen & 5.930 & 5.904 & 5.867 & 5.854 & 5.769 & 5.713 & 5.668 & 5.499 & 5.272 & 5.133 & 4.920 \\
Estonia & 2.143 & 2.188 & 2.145 & 2.111 & 2.094 & 2.078 & 2.095 & 2.075 & 2.014 & 2.011 & 2.029
\end{tabular}

Sources: Borisov and Kiseleva, 1981, 12; the calculations for 1980-81 have been completed on the basis of data published in Vestnik statistiki, 1982, No. 11, 65.

It is well known that crude rates have several deficiencies, since their values are significantly affected by the age, sex, and marital structures of the population. Thus, after reaching its minimum, (17.0 per thousand) in 1969 , the crude birth rate has grown year by year almost uninterruptedly already reaching 18.9 per thousand in 1982. However, an analysis of more sophisticated indicators of fertility discloses that, in fact, the level of fertility continued to decline in the 1970s. This, among other things, can be seen from Table 2 representing the development of the total fertility rates.

The total fertility rate for the whole Soviet Union - after it had for a short time risen slightly, from 2.389 in $1969-70$ to 2.469 in $1971-72$ - has declined continuosly and by $1980-81$ its value was 2.254 , i.e. it was less than in $1969-70$ (at the same time the crude birth rate, on the contrary, showed an upward trend). 
One essential peculiarity in the current demographic development of the Soviet Union is the highly differential fertility between various regions of the country (see Table 2). At the same time, differences can be seen between the union republics constituting the USSR in the patterns of how the total fertility rates have developed over time.

In most of the republics, as well as in the USSR on the average, a short-term upward swing of the total fertility rate was observed from 1970 to 1972 - except in the union republics of Georgia, Azerbaidzhan, Armenia, and Turkmenia SSRs in which such a rise was not experienced. In the Uzbek SSR, in turn, the total fertility rate continued to climb until 1973, and in the Tadzik SSR till 1975-76, after which it began to fall relatively rapidly.

It is of certain interest to examine the fertility trends of the titular nationalities of the union republics. This is possible by using the data on the number of each of the nationalities provided by the 1959, 1970, and 1979 All-union censuses and by employing a method designed by B. Ts. Urlanis (1974, 131-132). Supposing that the total increase of each of the 15 titular nationalities was equal to their natural increase and that the crude death rate was at the same level as the average figure of the respective republic, Urlanis estimated average crude birth rates for the nationalities in the period between the 1959 and 1970 censuses. On the basis of the 1979 census returns and by the method mentioned we estimated average crude birth rates of the 15 titular nationalities of the union republics for the 1970-1978 intercensal period and obtained a picture of their development over time (see Table 3 ).

The results presented in Table 3 show that in 1970s the birth rates of almost all of the nationalities fell and the decline was most conspicuous among the Belorussians, Georgians, Azerbaidzhani, Kazakhs, Moldavians, and Armenians. In 20 years the Armenians completed the transition from the group of peoples with very high birth rates (over 40 per thousand) to the group which is characterized by medium level fertility. At present the Azerbaidzhani and Kazakhs are coming close to that group. This indicates that the demographic transition from high to relatively low fertility can occur quite rapidly under certain circumstances.

The birth rates of the Latvians and Estonians remained practically level (strictly speaking they even grew a little). However, it must be kept in mind that, firstly, the

$\mathrm{T}$ a b l e 3. Average birth and growth rates: titular nationalities of the 15 union republics during the intercensal years $1959-69$ and $1970-78$ per 1000 persons.

\begin{tabular}{|c|c|c|c|c|c|c|}
\hline & \multicolumn{3}{|c|}{ Fertility } & \multicolumn{3}{|c|}{ Growth } \\
\hline & $1959-69$ & $1970-78$ & $\begin{array}{l}\text { Growth } \\
\text { index }\end{array}$ & $1959-69$ & $1970-78$ & $\begin{array}{c}\text { Growth } \\
\text { index }\end{array}$ \\
\hline Latvians & 12.3 & 12.4 & 1.008 & 1.9 & 0.7 & 0.368 \\
\hline Estonians & 12.3 & 12.8 & 1.041 & 1.6 & 1.4 & 0.875 \\
\hline White Russians & 19.2 & 13.1 & 0.682 & 12.3 & 4.9 & 0.398 \\
\hline Ukrainians & 15.8 & 14.0 & 0.886 & 8.2 & 4.3 & 0.524 \\
\hline Russians & 18.9 & 16.5 & 0.873 & 11.2 & 7.0 & 0.625 \\
\hline Lithuanians & 20.5 & 16.8 & 0.820 & 12.4 & 7.5 & 0.605 \\
\hline Georgians & 24.0 & 18.4 & 0.767 & 17.1 & 10.7 & 0.626 \\
\hline Moldavians & 24.7 & 19.3 & 0.781 & 18.1 & 10.7 & 0.591 \\
\hline Armenians & 28.4 & 22.5 & 0.792 & 22.5 & 17.2 & 0.764 \\
\hline Kazakhs & 41.2 & 30.6 & 0.743 & 35.2 & 23.9 & 0.679 \\
\hline Azerbaidzhani & 43.7 & 31.7 & 0.725 & 36.9 & 25.1 & 0.680 \\
\hline Kirgiz & 44.1 & 38.4 & 0.871 & 37.5 & 30.7 & 0.819 \\
\hline Turkmen & 45.6 & 39.5 & 0.866 & 38.9 & 32.2 & 0.828 \\
\hline Uzbeks & 45.1 & 40.8 & 0.905 & 39.3 & 34.3 & 0.873 \\
\hline Tadzhiks & 45.2 & 41.9 & 0.927 & 39.4 & 34.5 & 0.876 \\
\hline
\end{tabular}

Source: Borisov and Kiseleva, 1981, 20. 
coefficients of the table are approximate estimates only (the small difference between them may thus be accidental), secondly, as all crude rates these also are affected by the improvements in marital and age structure, and, finally, the values of the rates stay at a low level among both of the nationalities.

The declining fertility and increase of families with a small number of children among a considerable section of the population of the country is confirmed by the findings of several studies, e.g. the sample surveys conducted from time to time by the Central Statistical Administration of the USSR. Thus, according to Table 4, in the whole USSR among the worker and employee families examined the share of families with one or two children rose from $84.6 \%$ in 1967 to $89.2 \%$ in 1978 .

$\mathrm{T} \mathrm{a} \mathrm{b} \mathrm{l} \mathrm{e} \mathrm{4.} \mathrm{Distribution} \mathrm{of} \mathrm{the} \mathrm{families} \mathrm{of} \mathrm{workers,} \mathrm{employees,} \mathrm{and} \mathrm{kolkhoz}$ peasants by the number of children under 16 years of age: USSR, according to surveys of the USSR Central Statistical Administration (in percent, the total number of families is taken as 100).

\begin{tabular}{lllllll} 
& Year & \multicolumn{5}{c}{ Number of children } \\
& & 1 & 2 & 3 & 4 & $5+$ \\
Blue and white collar & 1967 & & 54.5 & 9.5 & 3.3 & 2.6 \\
workers & 1972 & 53.3 & 33.4 & 7.7 & 2.9 & 2.7 \\
& 1978 & 57.4 & 31.8 & 6.4 & 2.3 & 2.1 \\
In towns & 1967 & 54.7 & 34.7 & 7.3 & 2.0 & 1.3 \\
& 1972 & 57.6 & 33.6 & 5.7 & 1.7 & 1.4 \\
& 1978 & 61.5 & 31.4 & 4.7 & 1.4 & 1.0 \\
In villages & 1967 & 34.3 & 34.1 & 16.9 & 7.9 & 6.8 \\
& 1972 & 38.1 & 32.9 & 14.8 & 6.8 & 7.4 \\
& 1978 & 44.2 & 33.1 & 11.7 & 5.3 & 5.7 \\
Members of agricultural & 1972 & 35.2 & 31.0 & 16.0 & 8.4 & 9.4 \\
cooperatives & 1978 & 37.9 & 30.2 & 14 & 7.6 & 9.7
\end{tabular}

Sources: Zhenshchiny i deti v SSSR, 1969, 112; Zhenshchiny SSSR, 1975, 92, 96; Deti v SSSR $1979,9$.

In urban areas the proportion of small families of the kind mentioned was already $92.9 \%$ in 1978 while in the countryside the corresponding figure was $77.3 \%$. Among kolkhoz peasant families the share of such families - $68.1 \%$ - was also fairly high. It can be added that in the low fertility republics these percentages are certainly higher.

Thus, as the foregoing discussion has shown, it is not the examination of crude birth rates - which have a number of serious deficiencies - but an analysis of indicators reflecting more adequately the changing intensity of reproductive behavior of the Soviet population that uncover the existent tendency in fertility toward a continuing decline or a stabilization on a not high level.

In this connection there is reason to note the high importance and timeliness of the steps in demographic policy implemented along the lines laid down by the 26th Congress of the CPSU with the aim to intensify public assistance to families with children, newly married couples and working mothers.

Of particular significance will be the financial support provided for young families, since the probability of having second and subsequent children depends to a high degree on the experience families have with caring for the first child. Material support to families with children and to newly married couples can exert an enduring influence not only on the expected but also on the ideal number of children (i.e. on the need for children) by elevating the prestige of families with children.

It is not, of course, correct to assert that with the activization of demographic policy all problems pertinent to fertility regulation will be immediately solved. 
However, the substantial measures of public support to families with children and to newly married couples which were taken in January 1981 to supplement the already existing state benefits have apparently begun to exert some influence towards a fertility increase. This becomes evident from the official statistical data: the share of children of third or higher parity has increased for the first time since 1966. In 1966 their share represented $38 \%$ of all births. By 1981 the figure had fallen to $22 \%$. In 1982 the share of new-born of third or higher parity accounted for $23 \%$ (Narkhoz 60, 70; Narkhoz 1982, 31).

During the years of Soviet rule mortality has declined rapidly, particularly in childhood, and the length of life has grown. It was already stated above that by $1971-72$, in comparison with prerevolutionary times, life expectancy more than doubled (from 32 to 70 years) (Narkhoz 1979, 436; Narkhoz 1967, 36).

A basically uniform pattern of mortality has emerged among the Soviet population. It is characterized by the predominance of such causes of death as cardiovascular diseases, malignant neoplasms, traumas, and some diseases of a non-infectious (endogenous) type. A death cause structure of this kind is pertinent to developed countries having a high life expectancy.

The rapid decline of mortality in our country was accomplished thanks to the attention paid by the Communist Party and the Soviet state to the matters of improving the population's health - i.e. to the intensive development of free and accessible medical aid of good quality and to the implementation of a broad program of maternity and childhood care.

The crude death rate in the USSR is one of the lowest in the world (see Table 1). At the same time, however, it must be admitted that after a long decline the crude death rate - having reached a low of 6.9 per thousand in 1964 - began to rise. During the last few years it has shown a clear tendency to increase, in 1982 the rate was 10.1 per thousand. To a large degree this situation is caused by the changes in the age composition of the population, by the aging of the population. The values of the death rate also display a very clear differentiation by republics, which indicates their close dependence on the age structure, particularly on the proportion of elderly people. The lowest death rate in 1982 was in Armenia (5.5 per thousand) where the proportion of the population in the young age-groups is high. In the Latvian SSR, in turn, the death rate was highest, 12.2 per thousand. Among the union republics Latvia has the largest proportion of people aged 60 years and over (Narkhoz 1982, 30).

It is also possible to note some differentiation in mortality by sex and age in distinct regions of the country caused by disparities in the levels of infant mortality and by different levels of mortality among people of working age, which, in turn, to a large extent depends on the special features of the economic structure of the regions. It is known that the incidence of a number of diseases and of industrial traumatism has certain differentiation according to the branch of industry.

The care of the population's health constitutes one of the principal tasks of the Soviet social policy. A wide and well-developed network of free medical aid exists in the USSR. In 1982 the number of medical practitioners in the USSR was over one million - a figure which represents more than a third of all physicians in the world (Narkhoz 1982, 32-33; Vsesoiuznaia 1926, 172).

Nonetheless, it must be, taken into consideration that currently - apart from the period of intensive decline in mortality, when preventive, curative, and hygienic measures played a decisive role in the reduction of infectious and other serious diseases - the mortality level depends not solely on the activities of the medical establishment but also on environmental influences, ways of life, behavior, and the spread of harmful habits among the population. Alcoholism, smoking, unsuitable diet, lack of physical exercise, etc. are often mentioned among the factors with which the rising mortality is connected.

Hence, at present, the population's health and in several cases also the growth of mortality depends to a large degree on the sociohygienic culture of behavior and on peculiarities of the way of life of the people. For this reason it is necessary that, 
$\mathrm{T}$ a b l e 5. Gross reproduction rates: USSR and union republics, from $1958-59$ to $1980-81$.

$\begin{array}{llllll}\text { USSR and union } & 1958- & 1974- & 1977- & 1978- & 1980- \\ \text { republics } & 1959 & 1975 & 1978 & 1979 & 1981 \\ \text { USSR } & 1.36 & 1.18 & 1.13 & 1.11 & 1.09 \\ \text { Russian SFSR } & 1.27 & 0.98 & 0.94 & 0.92 & 0.92 \\ \text { Ukraine } & 1.14 & 1.00 & 0.94 & 0.95 & 0.94 \\ \text { White Russia } & 1.36 & 1.08 & 1.00 & 0.99 & 0.98 \\ \text { Uzbek } & 2.45 & 2.79 & 2.54 & 2.47 & 2.33 \\ \text { Kazakh } & 2.16 & 1.62 & 1.52 & 1.47 & 1.41 \\ \text { Georgia } & 1.25 & 1.24 & 1.14 & 1.11 & 1.09 \\ \text { Azerbaidzhan } & 2.43 & 1.93 & 1.77 & 1.69 & 1.57 \\ \text { Lithuania } & 1.27 & 1.08 & 1.02 & 1.00 & 0.96 \\ \text { Moldavia } & 1.73 & 1.26 & 1.16 & 1.16 & 1.17 \\ \text { Latvia } & 1.08 & 0.97 & 0.91 & 0.90 & 0.92 \\ \text { Kirgiz SSR } & 2.09 & 2.33 & 2.21 & 2.14 & 1.98 \\ \text { Tadzhik } & 1.92 & 3.07 & 2.90 & 2.90 & 2.73 \\ \text { Armenia } & 2.29 & 1.38 & 1.26 & 1.19 & 1.13 \\ \text { Turkmen } & 2.48 & 2.83 & 2.67 & 2.56 & 2.37 \\ \text { Estonia } & 0.94 & 1.03 & 1.01 & 0.99 & 0.98\end{array}$

Calculated from: Naselenie 1979, 136-137; Vestnik statistiki 1976, No. 11, 86; 1979, No. 11, 66; 1980, No. 11, 76; 1982, No. 11, 65 .

along with the comprehensive measures implemented by the Soviet organs of medical care for the purpose of improving the population's health, the population itself also strives with greater vigor against such unhealthy habits as smoking, abuse of alcohol, and overeating which particularly in conjunction with the lack of physical exercise increase the risk of cardiovascular and other diseases.

Currently two distinct types of population reproduction exist in the USSR. The main difference between them lies in the intensity of fertility, since the intensity of mortality is approximately at the same level in the union republics and it largely depends on the age structure of the population in each republic.

In order to characterize the intensity of population reproduction of the union republics Table 5 provides data on the gross reproduction rates over a period of time.

On the basis of an analysis of indicators characterizing fertility, mortality, and the natural increase of population, it is possible to infer that the existence of two types of reproduction in the USSR - one with low fertility and low mortality and another with high fertility and low mortality - is a temporary phenomenon. The fall in fertility which occurs under the influence of fundamental socioeconomic changes is an inevitable and progressive process. At the same time Soviet demographers hold that a fertility decline to a level on which the number of people in the child generation may run below the size of the parent generation represents an extremely unfavorable phenomenon, which can have negative effects for the socioeconomic development of the country. In order to avoid this, it is necessary to pay serious attention to the design and realization of measures of an active demographic policy directed toward a stimulation of families to have second and third children. Only effective measures of an active demographic policy can push towards a rise in fertility in the regions where its level is very low.

The high speed of both fertility and mortality decline which is currently peculiar to the indigenous population of Central Asia and Caucasus will lead to the formation in the whole territory of the USSR of a unified pattern of population reproduction characterized by low fertility and mortality.

As was already stated, it is impossible to thoroughly study Soviet population development without a profound and comprehensive analysis of the dynamics and 
tendencies of the migration processes. Under Soviet circumstances, as a matter of fact, the migratory movement of population is one of the most important factors influencing both the socioeconomic development of the country and the natural increase of the population as well. This stems from the large scale and high intensity of migration and also from the fact that the people who are migrating are basically people in the ages with the highest working and reproduction potentials.

It is necessary to note that the volume of the migratory movement is determined both by the general rules governing the phenomenon itself and also by the specific conditions stemming from the socioeconomic, natural, and geographic circumstances in each given country.

In socioeconomic and demographic respects it is possible to delimit two fundamental processes in the migration of the Soviet population: firstly, the uninterrupted outmigration of rural inhabitants to urban areas and, secondly, the movement of people from different parts of the country - most of all from the developed regions - to the sparsely populated eastern and northern regions as well as to the territories in need of intensive economic development.

According to the existing estimates, annual migration in the USSR involves from 14 to 15 million people. This means that every year about $5 \%$ of the Soviet population migrate. It is 30 times higher than the intensity of migration in prerevolutionary Russia (Tarasova, 1981, 158).

The whole complex of profound socioeconomic changes realized in the USSR has influenced more or less the development of migratory processes. The industrialization and collectivization of agriculture formed the basis which made possible the full materialization of the regularity of the continuous outmigration of rural population into cities and other urban areas. This regularity is characteristic of all socialist countries, especially at the early stages of the construction of the new society and also where - as in the USSR - the agricultural sector dominated during the first postrevolutionary years. In the ensuing years the intense migration of rural inhabitants was due to the rising level of socialization of agricultural production and to the growth in productivity of agricultural work. This, as can be seen from Table 6, led to a decline in the size and the proportion of rural population.

$\mathrm{T}$ a b l e 6. The size and percentage of urban and rural population: USSR, selected years from 1913 to 1983 , in millions.

$\begin{array}{cccccc}\text { Year } & \begin{array}{c}\text { Total } \\ \text { population } \\ \text { (millions) }\end{array} & \begin{array}{c}\text { Urban } \\ \text { population } \\ \text { (millions) }\end{array} & \begin{array}{c}\text { Rural } \\ \text { population } \\ \text { (millions) }\end{array} & \begin{array}{c}\text { Urban } \\ \text { population } \\ \text { (percent) }\end{array} & \begin{array}{c}\text { Rural } \\ \text { population }\end{array} \\ \text { (percent) }\end{array}$

Sources: Narkhoz 1975, 7; Narkhoz 1980, 7; Narkhoz 1982, 5.

The volume of rural-urban migration in the Soviet Union has been fairly stable during the past few years. The mean annual increase of urban population due to migration gain from rural areas amounted to around 1.5 million people during the last two intercensal periods, i.e. between 1959 and 1979 (Narodonaselenie 1978, 461; Narodonaselenie 1980,3$)$. 
$\mathrm{T} \mathrm{a} \mathrm{b} \mathrm{le} \mathrm{7.} \mathrm{The} \mathrm{growth} \mathrm{of} \mathrm{urban} \mathrm{population} \mathrm{by} \mathrm{sources} \mathrm{of} \mathrm{increase:} \mathrm{USSR,} \mathrm{inter-}$ censal periods from 1926 to 1979 (in millions and in percent).

\begin{tabular}{|c|c|c|c|c|c|c|c|c|}
\hline \multirow{2}{*}{$\begin{array}{l}\text { Source of } \\
\text { increase }\end{array}$} & \multicolumn{2}{|c|}{$1926-1939$} & \multicolumn{2}{|c|}{$1939-1959$} & \multicolumn{2}{|c|}{$1959-1970$} & \multicolumn{2}{|c|}{$1970-1979$} \\
\hline & millions & $\%$ & millions & $\%$ & millions & $\%$ & millions & $\%$ \\
\hline Total growth & 29.8 & 100 & 39.6 & 100 & 36.0 & 100 & 27.6 & 100 \\
\hline from which: & & & & & & & & \\
\hline $\begin{array}{l}\text { Net growth of urban } \\
\text { municipalities by }\end{array}$ & & & & & & & & \\
\hline inmigration & 18.7 & 63 & 24.6 & 62 & 16.4 & 46 & 13.4 & \\
\hline $\begin{array}{l}\text { Growth by change of } \\
\text { rural municipalities to }\end{array}$ & & & & & & & & \\
\hline urban municipalities & 5.8 & 19 & 6.7 & 18 & 5.0 & 14 & 2.6 & \\
\hline Natural growth & 5.3 & 18 & 8.0 & 20 & 14.6 & 40 & 12.0 & 43 \\
\hline
\end{tabular}

Source: Korel', 1982, 36.

The migration of rural population to urban areas represents a very significant component in the total urban growth. It is possible to conclude from Table 7 that during the period between the 1926 and 1979 censuses more than half of the total increase of urban inhabitants came from this source.

The rapid urban growth is linked to the migration of rural population. In 1926 the urban population of the USSR amounted to 26.3 million, by 1983 the size of the population living in urban areas had grown to 174.6 million people. Of the total increase of 148.3 million people more than half is due to migration gains. The migrants from the countryside, however, not only heighten the number of urban residents. They also take an active part in the natural reproduction of urban population. It is also likely that during the first years of residence in urban areas the reproductive attitudes and fertility indicators among the arrivals from the countryside are higher than among the indigenous urban population.

The migration of rural population leads to changes in the social structure of society and in the occupational structure of the population; it also brings about substantial changes in ways of life and widens the migrants' potential perspectives, for instance, for social, professional and cultural advancement.

These results of migration to urban areas must be taken into account, if a general assessment of the population exchange between urban and rural localities is made. In the final analysis, rural migration, in spite of a number of negative features, secured the solution of the strategic task of the development of the USSR, i.e. the meeting of the demand of the industrial branches in the labor force (for some negative consequences of rural-urban migration, see Rybakovsky, Makarova, and Tarasova, $1984,75-88)$. Thus, in a historical perspective and from the viewpoint of industrial development, it is reasonable to admit the fairly effective nature of the migration of rural inhabitants.

An uninterrupted growth of the number and percentage of urban residents represents the main summary of the migration of rural population. The share of urban population in the country rose from $18 \%$ in 1926 to $64 \%$ in 1983 . During the Soviet period over 1,200 new cities or towns have been established. It can be added that before World War II only Moscow and Leningrad had a population of over one million. Between 1939 and 1959 Kiev entered the category of cities with more than one million inhabitants. By January 1, 1983 the number of Soviet cities with one million or more inhabitants had reached 22 (Narkhoz 1982, 22).

A second fundamental direction in the shaping of migration processes represents a response to the unwavering change in the locational pattern of the productive forces of the country. The change involves the raising of the economy in the former backward 
minority areas as well as in eastern and northern territories with huge natural resources. This variety represents the population movement mainly from densely populated habitations of long standing to sparsely populated new regions, such as Siberia, the Far East, Northern Kazakhstan, and Northern Russia. All over these regions, on the basis of virgin energy and raw material resources, new territorialproduction complexes (TPC) have been formed which attract considerable amounts of workforce. Thus, just between 1926 and 1939, about 5 million people moved to the Urals, Siberia, the Far East, Kazakhstan, and Central Asia. Around 2 million settled down in the Urals, 700,000 in the Kuznetsk coal base, 800,000 people went to the Far East where the population increased by over 1.7 times from 1930 to 1940 (Itogi Vsesoiuznoi perepisi naseleniia $1970 \mathrm{~g}, 1972,570$ ).

In recent years, particularly during the last few five-year periods, the intensive development of the productive forces and further populating have continued in the eastern and northern regions of the Russian Federation. These are connected with the extraction of Siberian oil and gas deposits, formation of new TPCs in Eastern Siberia, construction of the Baikal-Amur railway, etc.

It is necessary to note the profound consequences of World War II for the territorial redistribution of the population and for the migration during the post-war period as well. About 25 million people from the areas of the Ukraine, Belorussia, the Baltic Republics, and Western Russia, which were under threat of occupation, moved to the Urals, the Volga region, Siberia, and Central Asia. It is possible to get an idea of the scale of this migration by comparing the 1939 and 1959 population data. During that period the population of the Urals grew by $28.9 \%$, the corresponding combined figure for Siberia and the Far East was $35.4 \%$ and for the Central Asian Republics $29.9 \%$. At the same time, the population in the European part of the country grew only negligibly. Crude estimates show that from 1939 to 1959 a total of 8 to 10 million people moved from the European part of the USSR to the Asian part - including the Urals (Itogi Vsesoiuznoi perepisi naseleniia 1970 g., 1972, 570).

After the war the reconstruction of destroyed regions stimulated a return flow of population from the east. The migration back to the original regions of inhabitation was not, however, very intense and it was spread over a fairly prolonged period of time.

A factor of exceptional importance in raising the level of population mobility was the realization, in accordance with the Leninist plan of the construction of socialism, of cultural revolution, first of all, the eradication of illiteracy. Thus, in the age-group 9 to 49 years the share of literate persons was only $44.1 \%$ in 1920 , in 1926 the figure was $56.6 \%$ and at the beginning of 1939 already $87.4 \%$.

By the present time, the Soviet Union has been transformed not only into a country with complete literacy (the proportion of literate persons in ages 9 through 49 was $98.5 \%$ in $1959,99.7 \%$ in 1970 , and $99.8 \%$ in 1979) but also into a country with a high educational and cultural level among the population. For instance, in 1979 the number of people with a higher and full or incomplete secondary education was 638 per thousand inhabitants aged 10 years and over. In 1970, 1959, and 1939 the corresponding figures were 483, 361, and 100 respectively (Vsesoiuznaia 1926, 132; Vestnik statistiki, 1982, No. 7, 77). The growth of the educational level demonstrates the social development of the population - which also includes the growth of the population's mobility.

The comparison of the 1926 and 1979 data on the numerical relationship between the indigenous (proportion of those living in the same locality where they were born) and in-migrant inhabitants indicates a change in the level of population mobility. In the whole country the proportion of indigenous inhabitants amounted to $76 \%$ in 1926 . By 1979 the figure had fallen to $52.9 \%$. The share of non-indigenous inhabitants has grown in all regions, both in urban and rural localities. For instance, in the countryside of the Uzbek SSR it grew by three times (from $4 \%$ in 1926 to $11.8 \%$ in 1979). The in-migrant population, especially those who have lived in the new place of residence less than 10 years, the so-called newly migrated, are as a rule 
characterized by a significantly greater mobility than the rest of the population. In 1979 the share of newly migrated accounted for $47.5 \%$ of the non-indigenous inhabitants (Naselenie 1979, 20). When speaking about the rising mobility of the Soviet population, it is proper to note two principial moments. Firstly, the increase in territorial mobility has exerted and continues to exert considerable influence on population development. With the words »Unless the population becomes mobile, it cannot develop» V. I. Lenin himself emphasized that no school can give to the people what personal acquaintance with different conditions of life can give (Lenin, 1964, 251).

Secondly, the growth of population mobility did not occur in its own right) but under conditions of profound changes in the economic and social structure, under circumstances of intensive urbanization and fundamental changes in the location of productive forces. In this situation the rising mobility could be realized and channelled through planned migration processes which - if they are looked at historically and on a large scale - contributed to the solution of socioeconomic tasks encountering the country.

It is necessary, however, to note that at different times and in different parts of the country the direction and intensity of the migration flows have not always been rational. This has been the case especially during the post-war period when a number of migration phenomena have not corresponded to the interests of the national economy. For instance, some republics, particularly the Russian Federation and Belorussia, gave up a very large share of their rural inhabitants in the migration exchange with cities, while in the Uzbek and Tadzik SSRs, where the fertility and natural increase is on a high level, the outmigration of rural population remained negligible. As a result of the falling fertility and of the negative migration balance, the number of rural inhabitants declined in Russia, the Ukraine, and Belorussia. At the same time in the Central Asian countryside, where surplus labor exists, the population doubled.

The problems of adjustment (full adaptation) of newly migrated people are also part of the unfavorable migrational phenomena. This problem is pertinent mainly to the areas of intensive economic development where the formation of the permanent population is continuing. It can be pointed out that the formation of a permanent population in the needed areas is not necessary as such but because of the supply to the territorial-production complexes under construction with stable and qualified labor. The problem of adjustment applies mainly to the regions of the Northeast and to Siberia where, in spite of the positive migration balance, the volume of migration exchange is very large.

It can be noted that despite of difficulties of adjustment, the process of formation of permanent population in the areas of new settlement is becoming more effective. This is proved by the fact that a growing number of districts in Siberia and the Far East show a positive migration balance and that a growing percentage of migrants remain 5-10 years after their arrival where they settled. It can also be added that the problem of adjustment has lost its comprehensive character in the eastern and northern areas. Rather, it has been transformed into a selective problem because each area also includes areas where a permanent population already exists and where its formation is continuing.

It is necessary for the successful solution of the adjustment problem that in the areas of new settlement the level of living rises more rapidly than elsewhere. Further, in the future also the implementation of the new union-wide schemes of social policy must be introduced beginning in the new areas. Since most return migration occurs during the first two or three years - during the period of adaptation - it is also necessary to have benefits which are granted at the moment of arrival in the area of settlement.

The future territorial redistribution of population in accordance with the socioeconomic interests of the country becomes possible only when the basic problems pertinent to migration are solved purposefully. This presupposes an active migration 
policy which is integrated with the general social policy of the state. It is necessary to keep in mind that the migration regulations, particularly their organizational forms, are in need of continuous reform regarding the benefits applied. Attention must be paid also to the fact that the benefits interact not only with the socioeconomic development of the territories but also with the changing way of life of people in its entirety. For just this reason the composition and volume of benefits must be corrected to correspond both to the degree of economic advancement of the areas in question and to the development of the Soviet people's way of life. It may help to overcome certain conservatism existing in the execution of the benefits if they are carried into effect for a fixed time. The design of future benefits represents a continuous task, since the changes both in socioeconomic conditions and in the population's way of life make it necessary to introduce corresponding amendments to the instruments by which migration policy is implemented.

\section{References}

Borisov, V. A.; Kiseleva, G. P. (1981). Aktual'nye problemy vosproizvodstva naseleniia SSSR v svete reshenii XXVI s" ezda KPSS. In Problemy vosproizvodstva i migratsii naseleniia. Moscow.

Deti v SSSR. (1979.) Moscow.

Itogi Vsesoiuznoi perepisi naseleniia 1970 g. (1972). Vol. III. Moscow.

Korel', L. V. (1982). Peremeshchenie naseleniia mezhdu gorodom i selom v usloviiah urbanizatsii. Novosibirsk.

Lenin, V. I. (1964). Collected Works. 2nd Impression, Vol. 3. Moscow.

Narkhoz 1967 = Narodnoe khoziaistvo SSSR v 1967 g. (1968). Moscow.

Narkhoz 1975 = Narodnoe khoziaistvo SSSR v 1975 g. (1976). Moscow.

Narkhoz 1979 = Narodnoe khoziaistvo SSSR v 1975 g. (1980). Moscow.

Narkhoz $1980=$ Narodnoe khoziaistvo SSSR v 1980 g. (1981). Moscow.

Narkhoz 1982 = Narodnoe khoziaistvo SSSR v 1982 g. (1983). Moscow.

Narkhoz 60 = Narodnoe khoziaistvo SSSR za 60 let. (1977) Moscow.

Narodonaselenie $1978=$ Narodonaselenie stran mira. (1978). Spravochnik. Moscow.

Narodonaselenie $1980=$ Narodonaselenie stran mira. (1980). Spravochnik. Moscow.

Naselenie SSSR 1973. (1975). Statisticheskii sbornik. Moscow.

Naselenie 1979 = Naselenie SSSR. (1980). Po dannym Vsesoiuznoi perepisi naseleniia $1979 \mathrm{~g}$. Moscow.

Rashin, A. G. Naselenie Rossii za 100 let. (1966). Moscow.

Rybakovskij, L. L.; Makarova, L. V.; Tarasova, N. V., (1984). Migration processes, their direction and implications. In Proceedings of the First Finnish-Soviet Seminar on Demography. Helsinki, April 19-20, 1983, edited by Seppo Lallukka, pp 75-88. Publications of the Finnish Demographic Society, No. 8. Helsinki.

Tarasova, N. V. (1981). Vliianie migratsii na vosproizvodstvo naseleniia. In Problemy vosproizvodstva i migratsii naseleniia. Moscow.

Urlanis, B. Ts. (1974). Problemy dinamiki naseleniia SSSR. Moscow.

Vestnik statistiki: 1976, No. 11; 1979, No. 11; 1980, No. 11; 1980, Nos. 7 \& 11 .

Vsesoiuznaia 1926 = Vsesoiuznaia perepis' naseleniia 1926 g. (1931). Vol. 51 (SSSR). Moscow.

Vsesoiuznaia perepis' naseleniia. (1976). Sbornik statei. Moscow.

Zhenshchiny i deti v SSSR. (1969). Moscow.

Zhenshchiny SSSR. (1975). Moscow. 